\title{
Why Complexity?
}

\author{
BERNARD P. RICCA \\ St. John Fisher College (USA)
}

I'm currently working through - and it is work, not just light reading - Art Winfree's The Geometry of Biological Time (2000). In the Preface, Winfree wrote:

\begin{abstract}
Narrow expertise is a kind of provincialism, inducing arrogance, which, expressed as deafness, entrenches provincialism. This is a feedback loop familiar in most human clubs, whether composed of countryside villagers, physicists, doctors, molecular biologists, or prelates. In attempting this book I have to draw eclectically from such mutually isolated sources, abandoning aspiration to expertise ... but not abandoning the will to correct my errors of fact and of perspective. (p X)
\end{abstract}

Although Winfree was probably overly modest in describing his own intellect, his stance is, I believe, one that is very familiar to Complicity and its readers: Complicity readers, with the possible exception of this editor, have recognized expertise in some field, and many of us define our fields by their subject matters. However, we all come to Complicity, or so I'd like to believe, with a desire to move beyond the kind of provincialism of which Winfree writes. And while the results of these endeavors have been quite wonderful over the now 12 volumes of Complicity, I believe that we can also say more the status of Complicity than just "it's eclectic".

\section{Beyond subject matter}

Many have hinted at what might lie beyond subject matter definitions. Most disciplines seem to be defined by their subject matter: Biology is the study of living things, etc. Some examples, limited by my own field of "expertise" - and here, "expertise" translates as what I have formally studied, the people I have talked with, and various random titles that caught my eye give some insight into what is means to move beyond subject matter. Weinreich (1993) spoke of physics this way:

...we need to keep in mind that physics is rather different from the other sciences because, unlike them, it is not defined primarily by its subject matter. So, for example, we would agree that a problem validly belongs to biology if it deals with living things, or to geology if it deals with rocks, but no corresponding 
definition exists for physics. Instead, physics is delineated, not by its subject matter, but by the methods of thought that a physicist uses.

Continuing with the theme of physics, Watts (2004) gave what I consider to be the best description of physicists that I have ever encountered:

Physicists, it turns out, are almost perfectly suited to invading other people's disciplines, being not only extremely clever but also generally much less fussy than most about the problems they choose to study. Physicists tend to see themselves as the lords of the academic jungle, loftily regarding their own methods as above the ken of anybody else and jealously guarding their own terrain. But their alter egos are closer to scavengers, happy to borrow ideas and techniques from anywhere if they seem like they might be useful, and delighted to stomp all over someone else's problem. As irritating as this attitude can be to everybody else, the arrival of the physicists into a previously non-physics area of research often presages a period of great discovery and excitement. Mathematicians do the same thing occasionally, but no one descends with such fury and in so great a number as a pack of hungry physicists, adrenalized by the scent of a new problem.

Some fields see themselves, almost by definition, as transdisciplinary. Halliday (2006) once said:

...I have tried to use the term 'transdisciplinary'. In a sense it was my reaction to interdisciplinary, because 20 to 25 years ago in the universities we were all being told we've got to be interdisciplinary. And I said, fine, but that usually turned out to be what Basil Bernstein (2003) used to call a 'collection code'. You know a little bit of this, a little bit of that, a little bit of the other and I wanted to say what we need is something more transdisciplinary that redefines the structure of knowledge (p 114-115).

All three of these ideas, however, reference subject matter, even if it is in the attempt of escaping subject matter.

I believe that those who study complex systems are motivated by something more than the desire merely to escape the confines of a discipline defined by subject matter. The desire to escape these confines is a perfectly fine desire, and may be more academically acceptable than what I am about to say. However, I believe that we complexivists are interested in exploration, and are motivated by the desire to explore and to play ${ }^{1}$. We are largely not bound by our own formal backgrounds, or by the university/college-recognized description of our places in academia. (Indeed, we may even be best described by being those who reject disciplines whenever possible, and hence are seeking those spaces that Halliday seeks.) We may be serious about our play, and the pieces included in this issue deserve to be taken seriously, but what brings these pieces to this point is a sense of play by the contributors.

\section{Three Not-so-easy Pieces}

Play, however, is not always easy, and the three pieces included here are the result of a difficult process. All three, in one way or another, explore the notion of movement through time.

Koopmans asks researchers to move beyond "snapshots" of situations, and to consider what may occur over time scales that are longer than a single (or even few) measurements. Drawing from a result that was first put forth in the study of thermodynamics, he shows some ways in which the correlations (and, by implication, sometimes the lack of correlations,) that are near and dear to quantitative researchers may be less reliable or valid than is frequently believed. In particular, these "snapshots" of varying and changing research subjects (sic) is of

\footnotetext{
${ }^{1}$ Here I mean "play" and "explore” much as did Gregory Bateson.
} 
limited value. This use of ergodicity is one that, even for qualitative researchers, may change how one views the pictures drawn by research, for in essence, the ergodic assumption says that, given enough time, anything (and any series of events) may happen.

Sanford, Hopper, and Starr explore one endeavor that is explicitly rooted in change over time: a teacher education program at the University of Victoria. The particular focus of their exploration is on taking a relational view of the participants, rather than a merely mechanistic one. Relationships, by their very nature, extend over time, and often have a great deal of variation in them, and so although this piece may seem, one the surface, much different than Koopmans' contribution to this issue, there is a shared thread that runs through them: The silent partner in this case is that of relationships and time, which is essentially Whitehead's (1979) notion of process.

Barney \& Maughan continue the theme of relationship and time with an action research approach to the study of a single course in computer science. The goal of their study, however, is situated at a time which is earlier in the trajectory than the study of Sanford et al., being as much about design on the fly within a course as it is about exploring an already established course. In this way, the silent partner in Barney \& Maughan is Aoki (2005).

\section{Some editorial notes}

Having just completed my second volume as the Editor-in-Chief of Complicity, I wanted to make a few comments about patterns I discern in submissions and reviews, as well as other "newsy" items that relate to Complicity.

First, it appears that, even after 12 volumes of Complicity, and many more years of the study of complex systems, complexity is still very much a non-paradigmatic field. Whether or not the study of complexity should even endeavor to become a field with an overarching paradigm is an open question (and one which I'd be happy to discuss that with any of the readers at a convenient pub or coffeeshop, or to take pieces addressing that particular issue). However, given the non-paradigmatic nature of our play, it is necessary for all authors to be very clear about setting the ground rules for their submissions, to state precisely what they mean by "complexity". Hence, I ask that all future submissions to Complicity include a section near the beginning where the meanings of important terms and approaches are made clear to the reader. Although we have, as a community, become somewhat more uniform over the years about adopting similar understandings of concepts, there are still times when the review process is hampered because the editor/reviewer interprets ideas differently than the author. This is not intended to be a push towards greater paradigm-ization, but rather a plea to recognize that without a paradigm we must be more explicit to promote better discussion.

Second, I would like to introduce our new Book Review Editor, Sarah Pratt. Sarah is well known to many of you: She is an Assistant Professor at the University of North Texas (USA), her background includes mathematics education and curriculum studies, and she has been an active member and officer of the Chaos and Complexity Theories SIG of AERA for some time. I hope that you well read her introduction and the reviews found in this issue, and that you will consider contributing a review. 
Third, I want to thank our Scholarly Communications Editor, Don Gilstrap. After a long journey, I'm pleased to announce that Don has recently managed to get Complicity indexed in ERIC, which is one of the leading (English language) indices for educational research. This will certainly improve our readership and influence.

Fourth, I was able to recently attend the 2015 Conference on Complex Systems. Of the five hundred or so attendees (mostly physicists, generally stomping on problems in others' fields,) I would note that there were at most only three people in attendance who primarily view their field of study as being in education, and there was only one presentation on complexity and education (and that one concerned teaching students about complexity); there was a conference strand on "language, literacy, cognition and social systems" but even within that education was not really represented. I don't know what to make of these particular facts, but there does seem to be a gulf between the complexity and education community and the larger complexity community.

Last, given that we are near the Thanksgiving holidays here in the USA (yes, this issue is that late!), I want to thank many people who have contributed so much to Complicity's success. The journal's web-site lists the Editorial Team and my thanks go out to everyone there. From that list, I particularly want to thank our Assistant Editors Winnie Hunsburger, Michelle Jordan, and Randa Khattar, who (among their other jobs) do much of the behind-the-scenes work to get each issue out. And finally, I want to thank the contributors and reviewers, who together are responsible for the content that appears in the journal.

\section{References}

Aoki, T. (2005). Sonare and Videre: A Story, Three Echoes and a Lingering Note. In W. Pinar \& R. Irwin (Eds.), Curriculum in a new key: The collected works of Ted T. Aoki (pp. 367-376). Mahwah, NJ: Lawrence Erlbaum Associates.

Halliday, M. \& Burns, A. (2006). Applied Linguistics: thematic pursuits or disciplinary moorings? A conversation between Michael Halliday and Anne Burns. Journal of Applied Linguistics, 3(1), 113-128.

Watts, D. (2004). Six degrees: The science of a connected age, Open market edition (Kindle locations 963-970.) Norton. Kindle Edition.

Weinreich, G. (1993). Klopsteg Memorial Lecture (August, 1992): What science knows about violins - and what it does not know. American Journal of Physics., 61(12), 1067-1077.

Whitehead, A. (1979). Process and reality. New York, NY: Free Press.

Winfree, A. (2000). The geometry of biological time (2nd edition). New York, NY: Springer.

(C) Copyright 2015. The author, BERNARD P. RICCA, assign to the University of Alberta and other educational and non-profit institutions a non-exclusive license to use this document for personal use and in courses of instruction provided that the article is used in full and this copyright statement is reproduced. The authors also grant a non-exclusive license to the University of Alberta to publish this document in full on the World Wide Web, and for the document to be published on mirrors on the World Wide Web. Any other usage is prohibited without the express permission of the authors. 